\title{
Serum periostin levels following small bone fractures, long bone fractures and joint replacements: an observational study
}

\author{
Rachel Varughese ${ }^{1}$, Ruth Semprini ${ }^{1,2}$, Claire Munro ${ }^{1,5}$, James Fingleton ${ }^{1,5}$, Cecile Holweg ${ }^{3}$, Mark Weatherall ${ }^{1,4}$,
} Richard Beasley ${ }^{1,2,5}$ and Irene Braithwaite ${ }^{1,2,5^{*}}$ (1)

\begin{abstract}
Background: In asthma, serum periostin may potentially be used as a biomarker in the management of patients with Type-2 eosinophilic airway inflammation. However, serum periostin may be influenced by factors other than Type 2 inflammation, potentially confounding its interpretation. We aimed to measure change in periostin following bone injury.

Methods: 102 adults without asthma were recruited into three groups: joint replacement surgery, long bone fracture, short bone fracture. Participants underwent seven measurements of serum periostin over 26 weeks after bone injury, and prior to surgery in the joint replacement group. Differences in periostin were measured using a ratio of geometric mean (RGM), with comparison made with pre-surgery (joint replacement) or 26 week (long and short fracture) reference measurements.

Results: In the joint replacement group, periostin fell within $48 \mathrm{~h}$ (RGM 0.80, 95\% Cl 0.75-0.86), then increased to a maximum at 8 weeks (RGM 1.89, 1.77-2.02) and by 26 weeks remained above the reference measurement (RGM 1.27, 1.19-1.36). In the long bone fracture group, periostin was reduced at $48 \mathrm{~h}$ (RGM $0.76,0.71-0.83$ ) and then progressively increased to a maximum at 8 weeks (RGM 1.15, 1.06-1.23) compared with the reference measurement. In the short bone fracture group, periostin was reduced at $48 \mathrm{~h}$ (RGM 0.9, 0.85-0.95) but was not different from after week 1 compared with the reference measurement.
\end{abstract}

Conclusions: Serum periostin levels are influenced by bone injury. The timing and extent of bone injury needs consideration if periostin is used as a biomarker in the management of eosinophilic asthma.

Trial registration This trial was prospectively registered with the Australia New Zealand Trials Registry on Feb 72014 , (ACTRN12614000151639: https://www.anzctr.org.au/Trial/Registration/TrialReview.aspx?id=363881).

Keywords: Periostin, Bone healing, Asthma, Monoclonal antibody therapy

\section{Background}

In asthma, serum periostin may identify patients with Type-2 dependent eosinophilic airway inflammation [1], predict sputum eosinophilia and eosinophilic infiltration of the lung parenchyma [2], and in conjunction with high FeNO identify patients at highest risk of FEV1

\footnotetext{
*Correspondence: irene.braithwaite@mrinz.ac.nz

${ }^{1}$ Medical Research Institute of New Zealand, Private Bag 7902, Newtown, Wellington 6242, New Zealand

Full list of author information is available at the end of the article
}

decline and asthma exacerbation, regardless of inhaled corticosteroid (ICS) use [3]. Additionally serum periostin may identify patients who respond to monoclonal antibody therapy directed against interleukin (IL)-4 receptor alpha (R $\alpha)[4]$, IL-13 [5, 6] and immunoglobulin E (IgE) [7]. Serum periostin levels do not need to be adjusted to take account of a patient's age, sex, or common comorbidities [8], although periostin levels may be lower in smokers [8], in those with elevated BMI [8], and those with pre-extant osteoarthritis [9], and may be raised in a

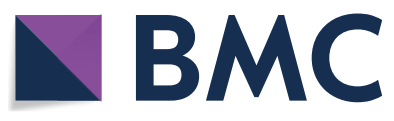

(c) The Author(s) 2018. This article is distributed under the terms of the Creative Commons Attribution 4.0 International License (http://creativecommons.org/licenses/by/4.0/), which permits unrestricted use, distribution, and reproduction in any medium, provided you give appropriate credit to the original author(s) and the source, provide a link to the Creative Commons license, and indicate if changes were made. The Creative Commons Public Domain Dedication waiver (http://creativecommons.org/ publicdomain/zero/1.0/) applies to the data made available in this article, unless otherwise stated. 
number of cancers [10]. Treatment with inhaled [11] or systemic [12] corticosteroids result in a modest reduction in serum periostin levels. Serum periostin may also be affected by factors other than those related to Type 2 inflammation or its treatment, such as bone injury. This is an important consideration as periostin is a matricellular protein which influences tissue development, remodeling and wound repair in adults [13]. Periostin levels have been shown to be elevated in patients with osteoporotic fracture [14], and in those who have suffered hip fracture [15]. The magnitude of the change in periostin relative to fracture size remains unquantified, as does the period of time in which serum periostin levels return to baseline.

Periostin, originally termed osteoblast-specific factor 2, was first identified in 1993 in mouse osteoblasts [16] and is encoded by the POSTN gene, located on chromosome 13 [17]. Its structure consists of a cysteine-rich domain at its N-terminal, four fasciclin-1 (FAS1) domains in the middle and an alternative splicing domain at its C-terminal [16]. These cysteine-rich domains are likely responsible for the binding of integrins, proteins which regulate cell adhesion and mobility [18], which are key in its role in connective tissue remodeling and repair. In asthma, Type-2 inflammatory cytokines IL-4 and IL-13 induce upregulation of the POSTN gene responsible for the encoding of periostin [19]. Periostin in turn binds to integrins on eosinophils, promoting localisation and adhesion to the airways [19], thereby promoting inflammation and fibrosis $[10,20]$. Not only does periostin exist in the basement membrane and mesenchymal tissues of the lung, periostin isomers exist in skeletal muscle, myocardium and heart valves, skin, periodontal ligaments, tendons, neoplastic tissues, and bones.

Periostin is so-named because high concentrations are found within periosteum [21], the layer of connective tissue surrounding bone. Periosteum in adults is composed of two layers: an outer, fibrous layer composed of fibroblasts and mesenchymal cells and an inner, osteogenic layer, which includes mesenchymal stem cells, osteoblasts and endothelial pericytes [22]. Cells in the inner layer are responsive to a wide range of growth factors and proteins and become highly active during bone remodeling, promoting callus formation and osteogenesis. The periosteum plays a central role in the process of fracture repair. Periostin release during bone injury is stimulated by the release of inflammatory cytokines, such as bone morphogenic proteins from the periosteum, which stimulate bone production [23]. In mouse models periostin is important for bone development and maintenance. In POSTN gene knock-out mice, affected animals have a dwarfism phenotype, reduced bone mass, and early periodontal disease $[18,24]$. Studies using murine models report that periostin mRNA is upregulated after fractures [25], consistent with the integral role periostin has in bone healing.

The aim of this study was to explore the time course of changes in serum periostin after bone injury of different types and severity. Our hypothesis was that serum periostin would increase following bone injury, with the magnitude and duration of any increase larger with bone injury of greater severity, thereby affecting the specificity of periostin in identifying patient endotypes and the ability to plan asthma treatment regimens.

\section{Methods}

This cohort study recruited 102 patients aged $18-75$ years from the emergency department, orthopedic fracture clinic, and pre-surgical assessment clinic at Wellington Regional Hospital, Wellington, New Zealand. Three groups of participants were recruited: those with short bone fractures, long bone fractures, and those scheduled for hip or knee arthroplasty. 'Short bones' included carpal, metacarpal, tarsal, metatarsal, or vertebral fractures. 'Long bones' included tibia, fibula, femur, humerus, radial, ulnar, or rib fractures. Participants were excluded from the study if they had conditions with the theoretical potential to affect serum periostin levels. These included: a doctor's diagnosis of asthma, bronchitis or chronic obstructive pulmonary disease (COPD); wheeze or use of respiratory inhalers in the previous 12 months; hospital admission, significant surgery (including dental surgery), bone fracture, or use of systemic corticosteroids, all within the 3 months prior to enrolment. Participants were also not recruited if they were pregnant or breastfeeding.

The study conformed to the standards of the Declaration of Helsinki; the Central Regional Ethics Committee of New Zealand granted ethical clearance (13/NTB/186), and written informed consent was obtained from all participants prior to testing.

Participants attended the Medical Research Institute of New Zealand (MRINZ) outpatient facility over a 26-week period (Additional file 1: Figure S1). Participants with fractures were enrolled within $48 \mathrm{~h}$ of their injury and then attended for visits at times of $1,2,4,8,12$ and 26 weeks after the fracture. Participants undergoing joint replacement surgery had an additional visit before the surgical procedure to obtain a sample for pre-operative serum periostin, and then were followed-up with the same visit schedule as the fracture groups.

At enrolment, participants completed a General Health Questionnaire, which was based on questions from the 
American Thoracic Society (ATS) Division of Lung Diseases-78 Questionnaire (DLD-78) [26] and measurement of their body mass index (BMI). Serum periostin was measured at every study visit, including the enrolment visit. Serum periostin was measured using the clinical trial version of the Elecsys ${ }^{\circledR}$ Periostin Immunoassay (Roche Diagnostics, Penzbery, Germany) described previously [27].

\section{Sample size}

The clinically important difference in serum periostin is not known. The sample size of 34 participants in each sub-group was based on detecting a paired difference in periostin of 0.5 of a standard deviation ( $80 \%$ power, Type I error rate $5 \%$, two-sided), which can be considered a 'medium' effect size. For comparison between long and short bone fractures groups, a sample size of 68 (34 in each group) was based on $90 \%$ power to detect a 0.8 standard deviation difference, which can be considered a 'large' effect size.

\section{Statistical methods}

The distribution of serum periostin was right skewed and therefore logarithmic data transformation was applied to the values for analysis purposes so as to meet normality assumptions of the statistical models. The inverse transformation of a difference in logarithms is equivalent to a ratio of geometric mean (RGM) periostin. Periostin values were plotted against time and a locally weighted scatter plot smoother (LOESS) with $90 \%$ confidence limits was used to illustrate the pattern of variation with time. Comparison between patient groups used mixed linear models with the individual participant as a random effect and a spatial exponential covariance matrix, using the time between measurements, to estimate the correlation between repeated measurements. Two sets of comparisons were estimated. Firstly, within group models were used to estimate the change from the reference measurement for each patient group; secondly an interaction between patient group and time was assessed. In the fracture groups, as a pre-fracture serum sample could not be obtained from participants, the initial analysis was performed using the first periostin measurement (taken within $48 \mathrm{~h}$ ) as the reference measurement. However, with the demonstration that the serum periostin falls within $48 \mathrm{~h}$ of bone injury associated with joint replacement surgery, it was apparent that the $48 \mathrm{~h}$ periostin levels could not be used as the reference measurement in the fracture groups. For this reason, a post hoc analysis was conducted where within group comparisons were estimated using the 26 week values as the reference measurement.

SAS version 9.4 was used.

\section{Results}

A total of 102 participants were recruited after 491 people were screened. The flow of participants through the study is shown in Fig. 1. Common reasons for screen failures included being outside of the designated age range, sustaining a fracture more than $48 \mathrm{~h}$ prior to screening, declining to participate, and having a doctor's diagnosis of asthma or COPD. The characteristics of study participants are shown in Table 1. The participants in the joint replacement group were older and had a higher BMI than those in the fracture groups.

\section{Joint replacement group}

In this group, there were 18 participants who underwent hip replacement surgery and 16 who had knee replacement surgery, with complete data available on between 31 and 34 participants at each time point. The mean (SD) length of time between the pre-operative reference measurement and the surgery was 46.6 (36.9) days (range 0-170 days). The pre-operative mean (SD) serum periostin was $54.2(18.0) \mathrm{ng} / \mathrm{ml}$.

Within $48 \mathrm{~h}$ of surgery, serum periostin levels fell to a mean (SD) of $43.5(12.5) \mathrm{ng} / \mathrm{ml}$, represented by a RGM periostin of $0.8, \mathrm{P}<0.001$ (Table 2). Serum periostin levels returned to baseline 1 week post-operatively and then progressively increased, with a maximum mean (SD) of $101.3(31.2) \mathrm{ng} / \mathrm{ml}$, (difference $46.9 \mathrm{ng} / \mathrm{ml}$, RGM periostin $1.89, \mathrm{P}<0.001)$ at 8 weeks. The periostin level then decreased, but remained above the pre-operative reference level at week 26, when the mean (SD) periostin level was $68.3(20.7) \mathrm{ng} / \mathrm{ml}$, difference $13.8 \mathrm{ng} / \mathrm{ml}$, RGM periostin 1.27, $\mathrm{P}<0.001$ (Fig. 2a).

\section{Long bone fracture group}

In this group, 22 had sustained lower limb long bone fractures and 12 sustained upper limb long bone fractures. In 13 participants there were two or more fractures, and there was complete data in 30 participants. The mean (SD) length of time between fracture and the first periostin sample was 1.1 (0.59) days, (range $0-2$ days). Given the fall in serum periostin level within $48 \mathrm{~h}$ after joint arthroplasty, a post hoc analysis was conducted using the 26 week value as the reference measurement. The mean (SD) periostin at 26 weeks was $56(16.3) \mathrm{ng} / \mathrm{ml}$.

Compared to the 26 week reference value, the mean (SD) periostin level at $48 \mathrm{~h}$ after fracture was lower at 42.7 (10.6) ng/ml, (difference $-13.4 \mathrm{ng} / \mathrm{ml}$, RGM periostin 0.76, $\mathrm{P}<0.001$ ) (Table 3). Periostin levels at week two were similar to the 26 week reference values, and then increased progressively to a maximum mean (SD) of $66.6(25.1) \mathrm{ng} / \mathrm{ml}$ at week 8 (difference $11 \mathrm{ng} / \mathrm{ml}$, RGM periostin 1.15, $\mathrm{P}<0.001$ ) (Fig. 2b). 


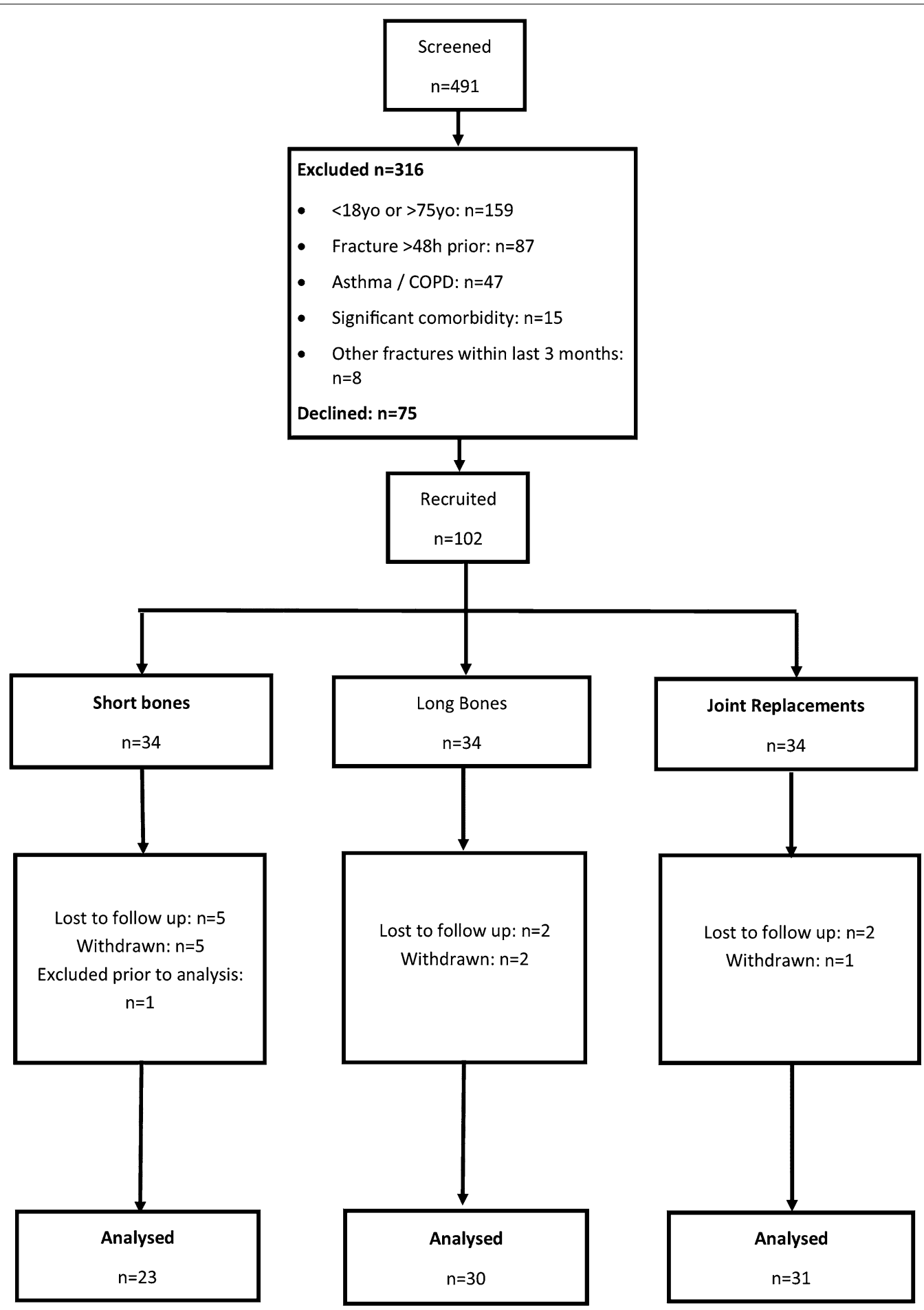

Fig. 1 The flow of participants through the study. Participant sustained iliac bone fracture but was allocated to small bone fracture group in error. Therefore excluded from analysis 
Table 1 Baseline participant characteristics for all participants

\begin{tabular}{|c|c|c|c|}
\hline & Joint replacement & Long bone fractures & Short bone fractures \\
\hline \multicolumn{4}{|l|}{ Continuous variables: $\mathrm{N}=34$} \\
\hline $\mathrm{Age}^{\mathrm{a}}:$ mean $(\mathrm{SD})$ & $60.6(10.1)$ & $47.9(17.4)$ & $39.8(15.7)$ \\
\hline $\mathrm{BMI}^{\mathrm{b}}$ : mean (SD) & $31.5(8.3)$ & $26.2(3.7)$ & $27.4(4.9)$ \\
\hline \multicolumn{4}{|c|}{ Categorical variables N/34 (\%) } \\
\hline Female (\%) & $16(47)$ & $21(62)$ & $12(35)$ \\
\hline Atopyc $(\%)$ & $17(50)$ & $18(53)$ & $16(47)$ \\
\hline Non-smoker (\%) & $31(91)$ & $29(85)$ & $27(79)$ \\
\hline \multicolumn{4}{|l|}{ Ethnicity } \\
\hline European (\%) & $24(71)$ & $27(79)$ & $28(82)$ \\
\hline Maori (\%) & $6(18)$ & $5(15)$ & $3(8)$ \\
\hline Pacific (\%) & $2(6)$ & $0(0)$ & $1(3)$ \\
\hline Asian (\%) & $1(3)$ & $1(3)$ & $1(3)$ \\
\hline Other (\%) & $1(3)$ & $1(3)$ & $1(3)$ \\
\hline \multicolumn{4}{|l|}{ Steroid medication ${ }^{d}$} \\
\hline Oral steroids (\%) & $1(3)$ & $0(0)$ & $0(0)$ \\
\hline Intranasal steroids (\%) & $1(3)$ & $0(0)$ & $4(12)$ \\
\hline Topical (\%) & $0(0)$ & $0(0)$ & $1(3)$ \\
\hline
\end{tabular}

$S D$ standard deviation, $I Q R$ interquartile range, $B M I$ body mass index, $n g$ nanogram, $\mathrm{m} / \mathrm{millilitre}$

a Age: years

b BMl: $\mathrm{kg} / \mathrm{m}^{2}$

c Atopy defined as a history of seasonal rhinoconjunctivitis and/or eczema

d Participants who took corticosteroid containing medication for any reason during the study period

Table 2 Serum periostin levels at time points in joint replacement group, and ratio of geometric means compared with pre-operative reference baseline value

\begin{tabular}{|c|c|c|c|c|c|}
\hline Visit & $\mathbf{N}$ & Periostin mean (SD) ${ }^{a}$ & $\begin{array}{l}\text { Change from baseline } \\
\text { Mean (SD) }\end{array}$ & Ratio of geometric means $(95 \% \mathrm{Cl})$ & $\mathbf{P}$ \\
\hline Pre-operative (reference) & 34 & $54.2(18.0)$ & - & - & - \\
\hline Within $48 \mathrm{~h}$ & 31 & $43.5(12.5)$ & $-11.5(9.7)$ & $0.80(0.75-0.86)$ & $<0.001$ \\
\hline Week 1 & 33 & $55.5(17.8)$ & $1.4(12.4)$ & $1.03(0.97-1.10)$ & 0.37 \\
\hline Week 2 & 32 & $79.0(27.0)$ & $24.0(17.3)$ & $1.44(1.35-1.54)$ & $<0.001$ \\
\hline Week 4 & 32 & $97.3(29.2)$ & $43.6(1.9)$ & $1.83(1.72-1.96)$ & $<0.001$ \\
\hline Week 8 & 31 & $101.3(31.2)$ & $46.9(22.6)$ & $1.89(1.77-2.02)$ & $<0.001$ \\
\hline Week 12 & 31 & $89.8(26.6)$ & $35.3(16.3)$ & $1.67(1.57-1.79)$ & $<0.001$ \\
\hline Week 26 & 31 & $68.3(20.7)$ & $13.8(12.8)$ & $1.27(1.19-1.36)$ & $<0.001$ \\
\hline
\end{tabular}

\section{Short bone fracture group}

Of the 34 participants recruited, 24 had complete data. Within this group: nine had sustained a metacarpal or carpal fracture, five had a metatarsal or tarsal fracture, 16 people had fractured phalanges (11 in the hand, five in the foot), two people had calcaneus fractures and one person fractured their talus. Three participants had sustained two or more fractures. The mean (SD) length of time between fracture and the first periostin sample was 1.29 (0.68) days, (range 0-2 days). The mean (SD) periostin at 26 weeks was $53(14.8) \mathrm{ng} / \mathrm{ml}$.
Compared with the 26 week reference value, the periostin level at $48 \mathrm{~h}$ was lower, with a mean (SD) of 46.1 (10) $\mathrm{ng} / \mathrm{ml}$ (difference $-5.7 \mathrm{ng} / \mathrm{ml}$, RGM periostin 0.9 , $\mathrm{P}<0.001$ ) (Table 4). Periostin levels at week two were similar to the 26 week measurements (mean $49.9 \mathrm{ng} / \mathrm{ml}$, difference $-2.4 \mathrm{ng} / \mathrm{ml}$, RGM periostin $0.97, \mathrm{P}=0.37)$ and did not change significantly after this time point (Fig. 2c).

Raw serum periostin values, for all three groups and all visits, are shown in Additional file 1: Table S1a-c. 

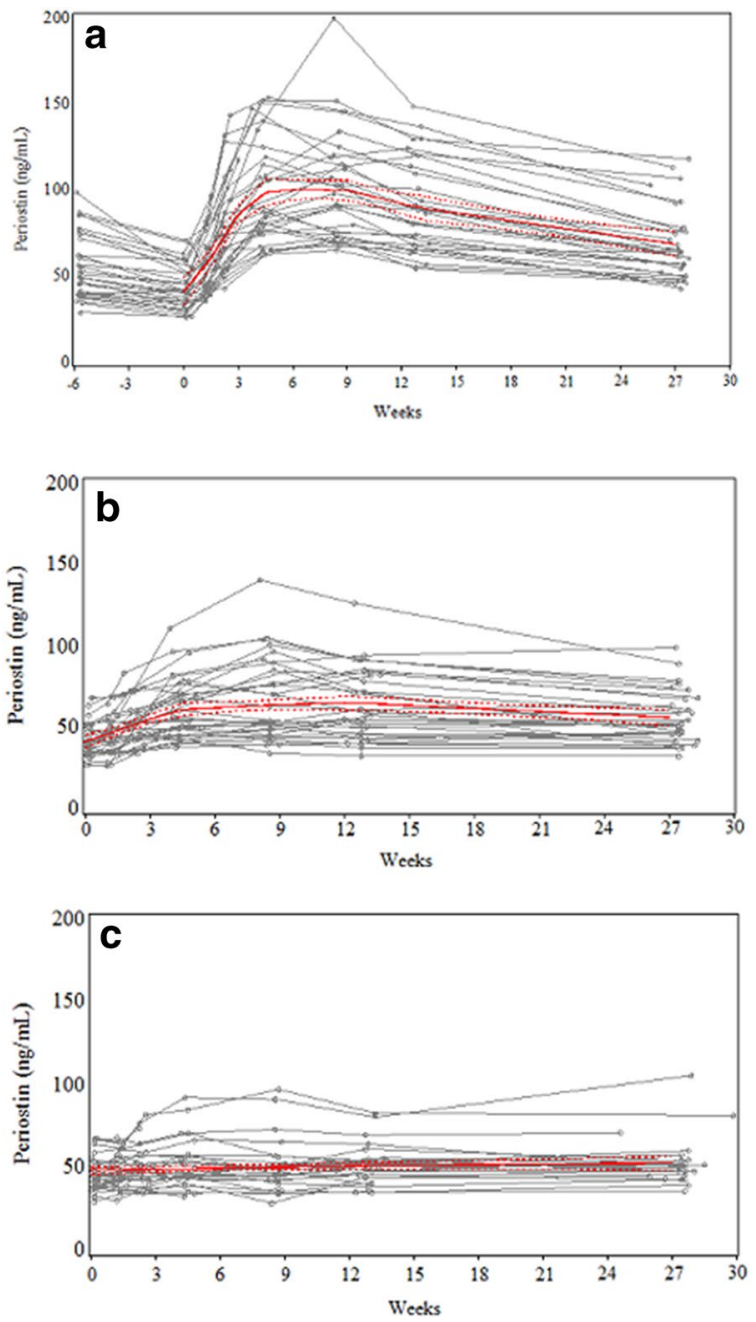

Fig. 2 a Time course of serum periostin levels over 26 weeks in participants who underwent large joint replacements (including pre-operative reference periostin values). b Time course of serum periostin levels over 26 weeks in participants who sustained a long bone fracture. c Time course of serum periostin levels over 26 weeks in participants who sustained a small bone fracture. The red solid lines denote the mean and the red dotted lines denote the 90\% confidence intervals

\section{Comparison between the groups}

The periostin levels were similar between the joint replacement and long fracture groups at $48 \mathrm{~h}$, but the joint replacement group had higher periostin levels at all subsequent time points to week 26 (Table 5 ).

The periostin levels were similar between the long bone fracture and short bone fracture groups at $48 \mathrm{~h}$ to week 2 . The long bone fracture group had higher periostin levels at weeks 4,8 and 16, but there was no difference between the two fracture groups at week 26 (Table 5).

\section{Discussion}

This study has shown that serum periostin levels are influenced by bone injury and repair. A biphasic response is apparent in which the periostin level fell in the first $48 \mathrm{~h}$ of injury, and then progressively increased over the following weeks as the bone repaired. The magnitude and duration of this increase in periostin levels was determined by the severity of the bone injury and associated soft tissue damage, with the periostin level increasing almost two-fold 8 weeks after joint replacement surgery, and still remaining above pre-surgery reference levels at 26 weeks. Additionally, even with small bones, measurement within the first 2 weeks of a fracture may result in a lower than usual periostin level. The clinical significance of these findings is that a history of the timing and extent of recent bone injury needs to be considered if serum periostin is to be used to guide treatment decisions in the management of eosinophilic asthma. The time-course of change in periostin levels in the immediate period after joint replacement surgery and long bone fracture is consistent with that seen in a previous study of periostin levels after hip fracture [15]. Elevated periostin levels with fracture have also been observed in patients with radiological evidence of osteoporotic fracture [14]. Neither of these studies obtained baseline periostin levels prior to fracture, which we were able to do in the joint replacement group.

We did not anticipate that there would be a biphasic pattern with the initial drop of serum periostin within $48 \mathrm{~h}$ of the index event, or the long duration of the subsequent progressive increase. However, these findings may be explained by the mechanisms of bone healing. Bone healing is a complex process involving a cascade of events and changes in the expression of several thousand genes. The physiological processes involved in fracture healing occurs in three stages: inflammatory, proliferative and reparative, and remodeling. The inflammatory phase occurs immediately, involving hematoma and granulation tissue formation. It is during this phase where pro-inflammatory molecules such as tumor necrosis factor- $\alpha$ (TNF$\alpha)$, IL-1 and IL- 6 , are secreted promoting angiogenesis and proliferation of osteoblasts and osteoclasts [28]. The acute inflammatory response peaks within the first $24 \mathrm{~h}$ and is complete after 7 days. The proliferative and reparative phase involves the proliferation and transformation of periosteal cells, production of a cartilaginous callus followed by resorption and replacement with new trabecular bone. During this phase osteogenic molecules, such as bone morphogenetic protein-2 (BMP-2), up-regulate periostin synthesis within the periosteum and the soft callus [23]. Murine models report high concentrations of periostin mRNA within immature osteoblasts in periosteal tissues within the first 3 days of fracture healing [25]. This 
Table 3 Serum periostin levels at time points in long bone fracture group, and ratio of geometric means compared with week 26 reference level

\begin{tabular}{|c|c|c|c|c|c|}
\hline Visit & $\mathbf{N}$ & Periostin mean $(\mathrm{SD})^{\mathrm{a}}$ & $\begin{array}{l}\text { Change from reference } \\
\text { Mean (SD) }\end{array}$ & Ratio of geometric means $(95 \% \mathrm{Cl})$ & $\mathbf{P}$ \\
\hline Within $48 \mathrm{~h}$ & 34 & $42.7(10.6)$ & $-13.4(12.4)$ & $0.76(0.71-0.83)$ & $<0.001$ \\
\hline Week 1 & 34 & $45.7(11.9)$ & $-11.2(10.9)$ & $0.81(0.76-0.88)$ & $<0.001$ \\
\hline Week 2 & 34 & $52.5(13.0)$ & $-3.7(8.2)$ & $0.94(0.87-1.02)$ & 0.12 \\
\hline Week 4 & 33 & $62.0(18.2)$ & $-5.8(10.9)$ & $1.10(1.02-1.18)$ & 0.015 \\
\hline Week 8 & 34 & $66.6(25.1)$ & $-11.0(16.1)$ & $1.15(1.06-1.23)$ & $<0.001$ \\
\hline Week 12 & 32 & $63.9(21.9)$ & $-7.7(10.9)$ & $1.11(1.04-1.20)$ & 0.004 \\
\hline Week 26 (reference) & 30 & $56.0(16.3)$ & - & - & - \\
\hline
\end{tabular}

a Units: $\mathrm{ng} / \mathrm{ml}$

Table 4 Serum periostin levels at time points in short bone fracture group, and ratio of geometric means compared with week 26 reference level

\begin{tabular}{|c|c|c|c|c|c|}
\hline Visit & $\mathbf{N}$ & Periostin mean (SD) ${ }^{a}$ & $\begin{array}{l}\text { Change from reference } \\
\text { Mean (SD) }\end{array}$ & Ratio of geometric means $(95 \% \mathrm{Cl})$ & $\mathbf{P}$ \\
\hline Within $48 \mathrm{~h}$ & 34 & $46.1(10.0)$ & $-5.7(14.8)$ & $0.90(0.85-0.95)$ & $<0.001$ \\
\hline Week 1 & 32 & $47.8(9.6)$ & $-3.5(11.2)$ & $0.93(0.88-0.99)$ & 0.021 \\
\hline Week 2 & 29 & $49.9(12.1)$ & $-2.4(7.8)$ & $0.97(0.93-1.03)$ & 0.37 \\
\hline Week 4 & 28 & $51.5(14.2)$ & $0.5(7.3)$ & $1.00(0.95-1.06)$ & 0.87 \\
\hline Week 8 & 27 & $50.6(15.7)$ & $-1.0(6.9)$ & $0.97(0.92-1.02)$ & 0.24 \\
\hline Week 12 & 27 & $51.6(12.1)$ & $-0.3(6.9)$ & $1.00(0.94-1.05)$ & 0.99 \\
\hline Week 26 (reference) & 24 & $53.0(14.8)$ & - & - & - \\
\hline
\end{tabular}

a Units: $\mathrm{ng} / \mathrm{ml}$

Table 5 Change in serum periostin over time: differences between the three groups

\begin{tabular}{|c|c|c|c|}
\hline Visit & Difference in logarithm periostin $(95 \% \mathrm{Cl})$ & $\begin{array}{l}\text { Ratio of geometric mean periostin }(95 \% \\
\mathrm{Cl})\end{array}$ & $\mathbf{P}$ \\
\hline \multicolumn{4}{|c|}{ Joint replacement minus long bone fracture } \\
\hline Within $48 \mathrm{~h}$ & $-0.01(-0.14$ to 0.12$)$ & $0.99(0.87-1.13)$ & 0.90 \\
\hline Week 1 & $0.18(0.05-0.31)$ & $1.20(1.05-1.37)$ & 0.007 \\
\hline Week 2 & $0.37(0.24-0.51)$ & $1.45(1.27-1.66)$ & $<0.001$ \\
\hline Week 4 & $0.47(0.34-0.60)$ & $1.59(1.40-1.82)$ & $<0.001$ \\
\hline Week 8 & $0.45(0.32-0.58)$ & $1.57(1.37-1.79)$ & $<0.001$ \\
\hline Week 12 & $0.36(0.23-0.49)$ & $1.43(1.25-1.63)$ & $<0.001$ \\
\hline Week 26 & $0.19(0.06-0.33)$ & $1.22(1.06-1.39)$ & 0.004 \\
\hline \multicolumn{4}{|c|}{ Long bone fracture minus short bone fracture } \\
\hline Within $48 \mathrm{~h}$ & $-0.09(-0.22$ to 0.04$)$ & $0.92(0.80-1.04)$ & 0.18 \\
\hline Week 1 & $-0.05(-0.18$ to 0.08$)$ & $0.95(0.84-1.08)$ & 0.45 \\
\hline Week 2 & 0.06 (- 0.07 to 0.19$)$ & $1.06(0.93-1.21)$ & 0.35 \\
\hline Week 4 & $0.19(0.06-0.32)$ & $1.21(1.06-1.38)$ & 0.005 \\
\hline Week 8 & $0.28(0.14-0.41)$ & $1.32(1.15-1.50)$ & $<0.001$ \\
\hline Week 12 & $0.21(0.07-0.34)$ & $1.23(1.08-1.40)$ & 0.002 \\
\hline Week 26 & $0.11(-0.03$ to 0.24$)$ & $1.11(0.97-1.27)$ & 0.11 \\
\hline
\end{tabular}

creates a periostin-rich environment resulting in the proliferation, differentiation and adhesion of osteoblasts [29]. The final process is remodeling, occurring from roughly 6-8 weeks after a fracture, whereby trabecular bone is resorbed by osteoclasts, and then compact bone is deposited within the resorption pit. During this phase, in mouse models, the periosteum's metabolic activity slows [25], resulting in a fall in periostin. 
It is possible that the immediate fall in serum periostin is due to the 'mopping up' of periostin as part of the inflammatory response. Alternatively, early periostin isoforms secreted by the periosteum may exert paracrine effects and not be measurable in serum, similar to that observed in cutaneous wound repair [30], resulting in lower serum periostin values. The later rise in serum periostin may be due to ongoing up-regulation of periostin synthesis, through the proliferative and reparative phases, resulting in excess production of periostin and its release into the circulation. These phases last for 6-8 weeks, consistent with the time course of the peak serum periostin in the joint arthroplasty and long bone fracture groups occurring 8 weeks after bone injury, after which the levels gradually reduced during the final remodeling phase. The widespread use of non-steroidal anti-inflammatory (NSAIDs) analgesics intra- and post-operatively, and also after the fractures, may have contributed to the patterns observed, with $60 \%$ of our patients using NSAIDs at some point during the study. Through inhibition of prostaglandins, NSAIDs impair or delay bone healing and decrease the integrity of the healing bone [31], an effect which may contribute to the slow and progressive rise in periostin levels.

There are a number of methodological issues that are relevant to the interpretation of the study findings. Three bone injury groups were studied to enable differing types and magnitudes of bone and associated soft tissue injury to be examined. The contribution of soft tissue injury to the changes in periostin levels may have been significant, as periostin is also secreted by tissue fibroblasts in response to injury [13]. Whether the bone was weight bearing was also likely to be a contributing factor, as mechanical stress in weight bearing bones is associated with periostin levels [32]. Although 16 participants fractured more than one bone, each participant was allocated to the group depending on the largest bone fractured, under the assumption that this would have the greatest influence on serum periostin values. While a number of other conditions such as atopic dermatitis [33], rhinosinusitis [34, 35], and malignancies [10, 36] may contribute to elevated periostin levels we did not utilize these as exclusion criteria. As this was a study of change in serum periostin after fracture, we considered that inclusion of patients with these conditions would not have influenced the findings. Serum periostin levels are lower in those with higher BMIs [8]. We analysed the mean change in periostin levels within each group after fracture and each patient was followed over time, serving as their own control. Therefore the results of the study are unlikely to be affected by variation in BMI. Periostin has been shown to be higher in children, likely due to bone growth [37], therefore we only recruited adults in whom we have shown age does not influence periostin levels [8]. Our decision not to exclude acute brain injuries, also known to contribute to elevate periostin levels [38], is likely to improve the generalizability of our findings.

Joint replacement surgery, which was chosen as the model of the greatest magnitude of bone and soft tissue damage, also provided the advantage of allowing a pre-injury periostin measurement to be obtained as a reference baseline. As it was not possible to obtain a prefracture sample from those who had sustained a fracture, the original intention was to use the $48 \mathrm{~h}$ periostin level as the reference baseline for the fracture groups, on the assumption that the periostin level would not have changed from pre-injury reference levels so soon after an injury. However, the $25 \%$ reduction in periostin level at this time point in the joint replacement group indicated that this may not be the case. It was for this reason that a post hoc decision was made to use the 26 week value as the reference measurement in both fracture groups.

This study recruited non-asthmatic participants, to minimize confounding of Type 2 inflammation on serum periostin levels if there were exacerbations during the study period, the treatment of which is known to influence periostin levels [12]. However, these results should be generalisable to asthmatics as there are no systematic differences in serum periostin between asthmatic and non-asthmatic adults [11]. Although inhaled and systemic steroids may have a modest short term effect on serum periostin levels, they were used in only 5 and $1 \%$ of participants respectively, and as long term treatment, and so this treatment is unlikely to have influenced the results.

\section{Conclusions}

In summary, serum periostin was influenced by bone and soft tissue injury, with a biphasic response, characterized by an initial fall in periostin levels in the first 1-2 weeks, followed by a progressive increase in serum periostin which peaked at 8 weeks, and in the case of bone and soft tissue injury associated with joint replacement surgery, was present for at least 26 weeks. These findings are clinically relevant if periostin is used in the future to guide management and treatment decisions such as identifying patients with eosinophilic airways inflammation, those at risk of FEV1 decline and/or increased asthma exacerbation risk, or who might most benefit from treatment with monoclonal antibody therapy directed against Type 2-related pathways including IL-4R $\alpha$, IL-13 and IgE in asthma.

\section{Additional file}

Additional file 1. Figure S1, Table S1a-S1C 


\section{Abbreviations}

ATS: American Thoracic Society; BMI: Body mass index; BMP: Bone morphogenetic protein; COPD: Chronic obstructive respiratory disease; IG: Immunoglobulin; IL: Interleukin; MRINZ: Medical Research Institute of New Zealand; mRNA: Messenger ribonucleic acid; NSAID: Non steroidal anti inflammatory drug; SD: Standard deviation; TNF: Tumor necrosis factor.

\section{Authors' contributions}

Study conception and design: RCS, JF, CH, MW, RB, IB; Acquisition of data: RV RS, TC, CM, RCS; Analysis: MW; Interpretation of data: RS, MW, RB, IB; Drafting of manuscript: All authors; Critical Revision: All authors; Accountable for all aspects of the work: All authors read and approved the final manuscript.

\section{Author details}

${ }^{1}$ Medical Research Institute of New Zealand, Private Bag 7902, Newtown, Wellington 6242, New Zealand. ${ }^{2}$ Victoria University of Wellington, Wellington, New Zealand. ${ }^{3}$ Genentech Inc, San Francisco, USA. ${ }^{4}$ University of Otago, Wellington, New Zealand. ${ }^{5}$ Capital \& Coast District Health Board, Wellington, New Zealand.

\section{Acknowledgements}

We would like to thank the participants, without whom we would not have been able to carry out this study. Special thanks to the Wellington Hospital Orthopaedic and Emergency departments who helped recruit participants for this study.

\section{Competing interests}

$\mathrm{RV}, \mathrm{RS}, \mathrm{CM}, \mathrm{JF}, \mathrm{MW}$ and IB have no competing interest to declare. $\mathrm{CH}$ is an employee of Genentech Inc., a member of the Roche group. RB reports grants from Genentech during the conduct of the study; personal fees from the Health Research Council of New Zealand, Glaxo Smith Kline, AstraZeneca, Chiese, Cephalon, Sanofi Aventis and Novartis outside the submitted work.

\section{Availability of data and materials}

The datasets generated and/or analysed during the current study are available from the corresponding author on reasonable request.

\section{Consent for publication}

Not applicable.

\section{Data integrity}

Dr Ruth Semprini had access to all data for this study and takes responsibility for Data Integrity and accuracy of the data analysis.

\section{Ethics approval and consent to participate}

The study conformed to the standards of the Declaration of Helsinki; the Central Regional Ethics Committee of New Zealand granted ethical clearance (13/ NTB/186), and written informed consent was obtained from all participants prior to testing.

\section{Funding}

Genentech Inc, USA

\section{Publisher's Note}

Springer Nature remains neutral with regard to jurisdictional claims in published maps and institutional affiliations.

Received: 18 December 2017 Accepted: 10 April 2018

Published online: 26 July 2018

\section{References}

1. Nair P, Kraft M. Serum periostin as a marker of Th2-dependent eosinophilic airway inflammation. J Allergy Clin Immunol. 2012;130:655-6.

2. Jia G, Erickson RW, Choy DF, Mosesova S, Wu LC, Solberg OD, et al. Periostin is a systemic biomarker of eosinophilic airway inflammation in asthmatic patients. J Allerg Clin Immunol. 2012;130(3):647-54.
3. Nagasaki T, Matsumoto H, Izuhara K, Tohda Y, Horiguchi T, Kita H, et al. Using exhaled nitric oxide and serum periostin as a composite marker to identify severe/steroid-insensitive asthma. Am J Respir Crit Care Med. 2014;190(12):1449-52.

4. Wenzel S, Swanson B, Teper A, Hamilton J, Izuhara K, Ohta S, et al. Dupilumab reduces severe exacerbations in periostin-high and periostinlow asthma patients. Abstracts form Conference: Vol. 48, European Respiratory Society. European Respiratory Society; 2016.

5. Corren J, Lemanske RFR, Hanania NNA, Korenblat PPE, Parsey MVM, Arron JRJ, et al. Lebrikizumab treatment in adults with asthma. N Engl J Med. 2011:365(12):1088-98.

6. Brightling CE, Chanez P, Leigh R, O'Byrne PM, Korn S, She D, et al. Efficacy and safety of tralokinumab in patients with severe uncontrolled asthma: a randomised, double-blind, placebo-controlled, phase $2 b$ trial. Lancet Respir Med. 2015;3(9):692-701.

7. Hanania NA, Noonan M, Corren J, Korenblat P, Zheng Y, Fischer SK, et al. Lebrikizumab in moderate-to-severe asthma: pooled data from two randomised placebo-controlled studies. Thorax. 2015:70(8):748-56.

8. Caswell-Smith R, Hosking A, Cripps T, Holweg C, Matthews J, Holliday $M$, et al. Reference ranges for serum periostin in a population without asthma or COPD. Lancet Respir Med. 2016;13(10):1-12.

9. Rousseau JC, Sornay-Rendu E, Bertholon C, Gernero P, Chapurlat R. Serum periostin is associated with prevalent knee osteoarthritis and disease incidence/progression in women: the OFELY study. Osteoarthr Cartil. 2015;23(10):1736-42

10. Conway SJ, Litvin J, Arron JR. The role of periostin in tissue remodeling across health and disease. Cell Mol Life Sci. 2014:71:1279-88.

11. Fingleton J, Braithwaite I, Travers J, Bowles D, Strik R, Siebers R, et al. Serum periostin in obstructive airways disease. Eur Respir J. 2016:47(5):1383-91.

12. Semprini R, Caswell-Smith R, Fingleton J, Holweg C, Matthews J, Weatherall $M$, et al. Longitudinal variation of serum periostin in adults with stable asthma. J Allergy Clin Immunol. 2017;139(5):1687-8.

13. Bornstein P. Matricellular proteins: an overview. Matrix Biol. 2000;19(7):555-6.

14. Kim B, Rhee Y, Kim CH, Baek KH, Min Y, Kim D, et al. Plasma periostin associates significantly with non-vertebral but not vertebral fractures in postmenopausal women: clinical evidence for the different effects of periostin depending on the skeletal site. Bone. 2015;81:435-41.

15. Yan J, Liu HJ, Li H, Chen L, Bian YQ, Zhao B. Circulating periostin levels increase in association with bone density loss and healing progression during the early phase of hip fracture in Chinese older women. Osteoporos Int. 2017:28:2335-41.

16. Takeshita S, Kikuno R, Tezuka K, Amann E. Osteoblast-specific factor 2: cloning of a putative bone adhesion protein with homology with the insect protein fasciclin I. Biochem J. 1993;294(Pt 1):271-8.

17. Merle B, Garnero P. The multiple facets of periostin in bone metabolism Osteoporos Int. 2012;23(4):1199-212.

18. Bonnet N, Standley KN, Bianchi EN, Stadelmann V, Foti M, Conway SJ, et al. The matricellular protein periostin is required for sost inhibition and the anabolic response to mechanical loading and physical activity. J Biol Chem. 2009:284(51):35939-50.

19. Izuhara K, Conway SJ, Moore BM, Matsumoto H, Holweg C, Matthews JG, et al. Roles of periostin in respiratory disorders. Am J Respir Crit Care Med. 2016;193(9):949-56

20. Chiappori A, deFerrari L, Folli C, Mauri P, Riccio AM, Canonica GW. Biomarkers and severe asthma: a critical appraisal. Clin Mol Allergy. 2015:13:20. https://doi.org/10.1186/s12948-015-0027-7.

21. Horiuchi K, Amizuka N, Takeshita S, Takamatsu H, Katsuura M, Ozawa H, et al. Identification and characterization of a novel protein, periostin, with restricted expression to periosteum and periodontal ligament and increased expression by transforming growth factor beta. J Bone Miner Res. 1999;14(7):1239-49.

22. Ueno T, Kagawa T, Mizukawa N, Nakamura H, Sugahara T, Yamamoto T. Cellular origin of endochondral ossification from grafted periosteum. Anat Rec. 2001;264(4):348-57.

23. Norris RA, Moreno-Rodriguez R, Hoffman S, Markwald RR. The many facets of the matricelluar protein periostin during cardiac development, remodeling, and pathophysiology. J Cell Commun Signal. 2009;3(3-4):275-86. 
24. Rios H, Koushik SV, Wang H, Wang J, Zhou H-M, Lindsley A, et al. Periostin null mice exhibit dwarfism, incisor enamel defects, and an early-onset periodontal disease-like phenotype. Mol Cell Biol. 2005;25(24):11131-44.

25. Nakazawa T, Nakajima A, Seki N, Okawa A, Kato M, Moriya H, et al. Gene expression of periostin in the early stage of fracture healing detected by cDNA microarray analysis. J Orthop Res. 2004;22(3):520-5.

26. Ferris BG. Epidemiology standardization project (American Thoracic Society). Am Rev Respir Dis. 1978;118(6 Pt 2):1-120.

27. Palme S, Christenson RH, Jortani SA, Ostlund RE, Kolm R, Kopal G, et al. Multicenter evaluation of analytical characteristics of the Elecsys $\left({ }^{\circledR}\right)$ Periostin immunoassay. Clin Biochem. 2017:50(3):139-44.

28. Marsell R, Einhorn TA. The biology of fracture healing. Injury. 2011:42(6):551-5

29. Zhu S, Barbe MF, Liu C, Hadjiargyrou M, Popoff SN, Rani S, et al. Periostinlike-factor in osteogenesis. J Cell Physiol. 2009;218(3):584-92.

30. Rosselli-Murai LK, Almeida LO, Zagni C, Galindo-Moreno P, Padial-Molina $\mathrm{M}$, Volk SL, et al. Periostin responds to mechanical stress and tension by activating the MTOR signaling pathway. PLoS ONE. 2013;8(12):e83580.

31. Cottrell J, O'Connor JP. Effect of non-steroidal anti-inflammatory drugs on bone healing. Pharmaceuticals (Basel). 2010:3(5):1668-93.

32. Bonnet N, Biver E, Durosier C, Chevalley T, Rizzoli R, Ferrari S. Additive genetic effects on circulating periostin contribute to the heritability of bone microstructure. J Clin Endocrinol Metab. 2015;100(7):E1014-21.
33. Kou K, Okawa T, Yamaguchi Y, Ono J, Inoue Y, Kohno M, et al. Periostin levels correlate with disease severity and chronicity in patients with atopic dermatitis. Br J Dermatol. 2014;171(2):283-91.

34. Laury AM, Hilgarth R, Nusrat A, Wise SK. Periostin and receptor activator of nuclear factor $\mathrm{k}-\mathrm{B}$ ligand expression in allergic fungal rhinosinusitis. Int Forum Allergy Rhinol. 2014;4(9):716-24.

35. Asano T, Kanemitsu Y, Takemura M, Yokota M, Fukumitsu K, Takeda N, et al. Serum periostin as a biomarker for comorbid chronic rhinosinusitis in patients with asthma. Ann Am Thorac Soc. 2017;14(5):667-75.

36. Tilman G, Mattiussi M, Brasseur F, van Baren N, Decottignies A. Human periostin gene expression in normal tissues, tumors and melanoma: evidences for periostin production by both stromal and melanoma cells. Mol Cancer. 2007:6(1):80.

37. Anderson HM, Lemanske RF, Arron JR, Holweg CT, Rajamanickam V, Gangnon $R E$, et al. Relationships among aeroallergen sensitization, peripheral blood eosinophils, and periostin in pediatric asthma development. J Allergy Clin Immunol. 2017;139(3):790-6.

38. Dong $X Q$, Yu WH, Du Q, Wang $H$, Zhu Q, Yang DB, et al. Serum periostin concentrations and outcomes after severe traumatic brain injury. Clin Chim Acta. 2017:471:298-303.
Ready to submit your research? Choose BMC and benefit from:

- fast, convenient online submission

- thorough peer review by experienced researchers in your field

- rapid publication on acceptance

- support for research data, including large and complex data types

- gold Open Access which fosters wider collaboration and increased citations

- maximum visibility for your research: over $100 \mathrm{M}$ website views per year

At BMC, research is always in progress.

Learn more biomedcentral.com/submissions 